\title{
Upwelling Irradiance below Sea Ice-PAR Intensities and Spectral Distributions
}

\author{
Lars Chresten Lund-Hansen ${ }^{1, *}\left(\mathbb{C}\right.$, Michael Bjerg-Nielsen ${ }^{1}$, Tanja Stratmann ${ }^{2,3}{ }^{\oplus}$, Ian Hawes ${ }^{4}(\mathbb{D}$ \\ and Brian K. Sorrell ${ }^{1}$ (D) \\ 1 Arctic Research Centre, Aquatic Section, Department of Biology, Aarhus University, Ole Worms Allé 1 Build. 1135, \\ 8000 Aarhus, Denmark; m.bjerg.nielsen@gmail.com (M.B.-N.); brian.sorrell@bio.au.dk (B.K.S.) \\ 2 Department of Earth Sciences, Utrecht University, Vening Meineszgebouw A, Princetonlaan 8a, \\ 3584 CB Utrecht, The Netherlands; tanja.stratmann@nioz.nl \\ 3 HGF MPG Joint Research Group for Deep-Sea Ecology and Technology, Max Planck Institute for Marine \\ Microbiology, Celsiusstrasse 1, 28359 Bremen, Germany \\ 4 Coastal Marine Field Station, Waikato University, Sulphur Point, Tauranga 3110, New Zealand; \\ ian.hawes@waikato.ac.nz \\ * Correspondence: lund-hansen@bio.au.dk
}

check for updates

Citation: Lund-Hansen, L.C.; Bjerg-Nielsen, M.; Stratmann, T.; Hawes, I.; Sorrell, B.K. Upwelling Irradiance below Sea Ice-PAR Intensities and Spectral Distributions. J. Mar. Sci. Eng. 2021, 9, 830. https:// doi.org/10.3390/jmse9080830

Academic Editor: Pedro Reis Costa

Received: 7 June 2021

Accepted: 29 July 2021

Published: 30 July 2021

Publisher's Note: MDPI stays neutral with regard to jurisdictional claims in published maps and institutional affiliations.

Copyright: (c) 2021 by the authors. Licensee MDPI, Basel, Switzerland. This article is an open access article distributed under the terms and conditions of the Creative Commons Attribution (CC BY) license (https:/ / creativecommons.org/licenses/by/ $4.0 /)$.

\begin{abstract}
Upwelling and downwelling spectral (320-920 nm) distributions and photosynthetic active radiation (PAR) intensities were measured below a first-year land-fast sea ice in a western Greenland fjord with and without a snow cover. Time-series of surface upwelling PAR, downwelling PAR, and under-ice PAR were also obtained. Spectral distributions of upwelling and downwelling irradiances were similar except for reduced intensities in the UV, the red, and NIR parts of the spectrum when the ice was snow-covered. Upwelling PAR amounted to about $10 \%$ of downwelling intensities, giving $5.1 \mu \mathrm{mol}$ photons $\mathrm{m}^{-2} \mathrm{~s}^{-1}$ at the bottom of the ice with a snow cover and $8.2 \mu \mathrm{mol}$ photons $\mathrm{m}^{-2} \mathrm{~s}^{-1}$ without. PAR partitioning analyses showed that the upwelling was related to scattering by suspended particles in the water column. A snow melt increased under-ice daily maximum downwelling PAR from 50 to $180 \mu \mathrm{mol}$ photons $\mathrm{m}^{-2} \mathrm{~s}^{-1}$ and overall under-ice PAR of 55 and $198 \mu \mathrm{mol}$ photons $\mathrm{m}^{-2} \mathrm{~s}^{-1}$ with $10 \%$ upwelling. It is concluded that upwelling PAR below sea ice might be an important factor regarding sea ice algae photophysiology and performance with a 10\% higher PAR; specifically when $\mathrm{PAR}>E_{\mathrm{k}}$ the light saturation point of the sea ice algae.
\end{abstract}

Keywords: sea ice; upwelling and downwelling irradiances; PAR; low light adapted ice algae; Greenland

\section{Introduction}

Nearly $10 \%$ of the surface of the earth is covered by sea ice, at its maximum extent in both the Arctic and Antarctic [1,2], and sea ice has a significant role in the Earth's climate due to its high albedo, whereby $50-80 \%$ of upcoming radiation is reflected [3]. Sea ice is an ecosystem with defined pathways of matter and energy [4], and several organisms, from bacteria to polar bears, rely and depend on sea ice for maintaining their life cycles [5]. Ice algae residing at the bottom of the sea ice and in the brine channels contribute about $10 \%$ of the total marine-produced carbon [6]. They bloom in the early spring when light reaches the bottom of the sea ice, often passing a snow pack of variable thickness. Most of these microalgae are acclimated to low light conditions [7-9]. For instance, active sea ice algae photosynthesis has been observed at just $0.17 \mu \mathrm{mol}$ photons $\mathrm{m}^{-2} \mathrm{~s}^{-1}$ at the bottom of a $1 \mathrm{~m}$ thick sea ice cover with $0.9 \mathrm{~m}$ snow [10]. Light is the main limiting factor for sea ice algae in early spring, as nutrient concentrations are still relatively high in the water column [11]. Irradiance at the sea ice-water interface is in-part regulated by the downwelling irradiance from the atmosphere, albedo of the snow and ice, and snow and ice thickness. The absorption and scattering in the snow and ice packs are related to snow age, temperature, water content [12], and, especially, brine and gas volumes in the sea ice [13]. 
There are further solid and dissolved substances in the snow and sea ice pack that either scatter or absorb the irradiance, including CDOM, chlorophyll $a(\mathrm{Chl} a)$, self-shading by algae, particulate matter, and diverse impurities [14]. In open and ice-free waters, some of the irradiance that reaches the oceans is reflected back to the water-air interface, as a result of scattering, and enters the atmosphere as water-leaving radiance [15]. This signal and its spectral composition are applied, for example, in multiple remote sensing applications for measuring Chl $a$ and suspended particulate matter concentrations in the oceans [16]. The water-leaving radiance signal has been applied in sea ice-covered areas for Chl $a$ and optical properties of the water column [17]. The intensity and spectral composition of the waterleaving radiance depends on the optical properties of the water column constituents, such as its dissolved and solid substances [18]. Under-ice light intensities are several times lower than in an ice-free water column, but there is still an upwards-directed irradiance, termed upwelling irradiance [19]. There are, to the authors knowledge, not many specific studies of the upwelling irradiances below sea ice. We here report the results of a study where we measured vertically and spectrally resolved upwelling and downwelling irradiance and photosynthetic active radiation (PAR) below a first-year land-fast sea ice.

We raise the following questions: (1) What is the intensity of the upwelling irradiance below the sea ice; (2) are there any differences in spectral composition of the upwelling and downwelling irradiances; (3) which optical properties in the water column regulate the intensity of the upwelling irradiance and discuss the potential effects that upwelling irradiance might have on low-light adapted ice algae [20].

\section{Materials and Methods}

\subsection{Study Area and Sampling}

Measurements and sampling were carried out at $66^{\circ} 56.370^{\prime} \mathrm{N}, 50^{\circ} 59.280^{\prime} \mathrm{W}$ in early March 2013 on first-year land-fast sea ice in the Kangerlussuaq estuary (Figure 1a). The estuary is only affected by inflowing, highly turbid meltwater from the Greenland inland ice (GrIS) between May and September [21]. The estuary, its optical conditions, the snow and ice, and its primary production are described previously [22-24]. The present study was part of a larger research program carried out on the ice between 11 and 20 March 2013, which had a focus on the effects of loss of snow cover on biological and photobiological conditions of the sea ice algae as reported elsewhere in this Special Issue [25]. In the present work we report upwelling and downwelling irradiances below the sea ice, both with and without a snow cover, along with measurements of sea ice and snow thickness, sea ice properties including bulk salinity, brine and gas volumes, temperature, and Chl $a$ content in the ice. Physical and optical properties of the water column below the ice were measured as depth profiles of salinity, temperature, $\mathrm{Chl} a$, and suspended particulate matter (SPM) concentrations.

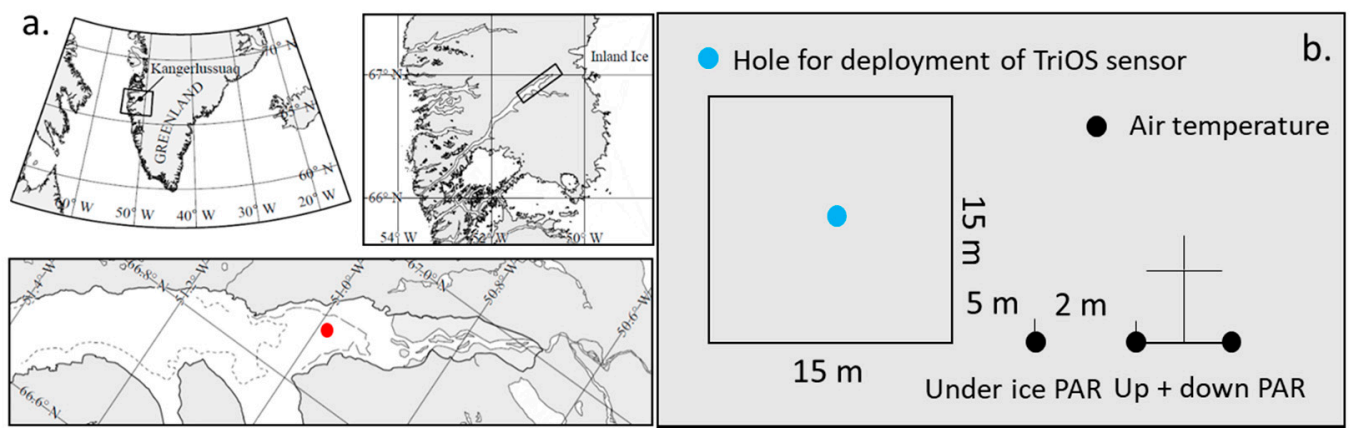

Figure 1. Red dot shows the location of the study site in the inner reach of Kangerlussuaq (a) (map redrawn from Nielsen et al. 2010), and optical field site with placement of sensors (not to scale) and spectral measurement site (b). Spectral data (TriOS) were obtained on 14 March and continous upwelling, downwelling, and under-ice PAR data were obtained from mid 12 to mid 19 March. 


\subsection{Optical Measurements}

Time series were obtained at the site for surface downwelling PAR and upwelling PAR measured at $0.5 \mathrm{~m}$ above the surface for albedo with two Li-Cor sensors (LI-COR LI-190R Quantum Sensor) marked Up + Down PAR (Figure 1b). A third Li-Cor sensor (LI-COR LI-192 Underwater Quantum Sensor) was mounted at $3 \mathrm{~cm}$ below the ice to measure downwelling PAR (marked as under ice PAR), with all sensors connected to a datalogger (Figure 1b). The under-ice sensor was mounted on a stick and kept in place by a frame until the stick was frozen into the ice. Sensors were placed at the site with an even and uniform snow cover, and great care was taken to keep disturbance of the snow cover to a minimum. Transmittance was given by the ratio between under-ice downwelling PAR and surface downwelling PAR. Under-ice spectral irradiance was measured with a recently (0.5 yr) purchased and calibrated TriOS Ramses ACC VIS cosine-corrected hyperspectral radiometer (Radiometer-TriOS Mess- und Datentechnik). The measuring range of the TriOS sensor was $320-920 \mathrm{~nm}$ with a spectral resolution of $1.3 \mathrm{~nm}$, and connected to a PC with a cable running the TriOS standard software. The sensor was mounted on an articulated L-arm and deployed through a hole with a diameter of $9.0 \mathrm{~cm}$ drilled with a Mark II Kovacs ice corer. Distance between hole and measuring point was $1 \mathrm{~m}$. Triplicate measurements of downwelling irradiances were obtained from $3 \mathrm{~cm}$ below the bottom of the sea ice and down to a depth of 8.0-9.0 m with a vertical resolution of $0.5 \mathrm{~m}$. The TriOS optical sensor was subsequently mounted to measure upwelling irradiances, also in triplicate, with a $0.5 \mathrm{~m}$ depth resolution down to $3.5-4.0 \mathrm{~m}$ depth. Sensor measuring depths were given to an accuracy of $1 \mathrm{~cm}$ by a calibrated pressure sensor system mounted on the L-arm and connected with a cable to a PC on the surface of the ice. Spectral measurements were carried out in two stages: (1) upwelling and downwelling with an intact snow cover and (2) upwelling and downwelling with no snow cover where it was removed manually, forming a snow free rectangle 15 by $15 \mathrm{~m}$ with the deployment hole in the middle (Figure 1b). All TriOS spectral measurements were carried out on 14 March 2013 between 1:20 and 2:20 PM with a clear and sunny sky. The PAR site with the three PAR sensors was established at 11:10 AM on 12 March with continous recordings every five minutes until 00:30 PM 19 March. Air temperature was recored every $5 \mathrm{~min}$ at $1 \mathrm{~m}$ above snow surface at the experimental site (Figure $1 b$ ).

\subsection{Ice Cores, Bulk Salinity, and Temperatures}

Snow cover thickness at the experimental site was measured to the nearest $0.1 \mathrm{~cm}$ with a ruler, and ice cores were collected using a Mark II Kovacs corer with an inner diameter of $9.0 \mathrm{~cm}$. Sea ice temperatures were measured by drilling a $3 \mathrm{~mm}$ thick hole to the center of the ice core and measured to the nearest $0.1^{\circ} \mathrm{C}$ with a digital thermometer Testo Thermometers (Temperature measuring instruments with connectable probes I DK-Site). Total length of the ice core was measured to nearest $0.1 \mathrm{~cm}$. The cores were cut into $5 \mathrm{~cm}$ thick slices with a stainless steel saw and placed in sealed polyethylene bags and brought back to the laboratory at Kangerlussuaq International Science Support (KISS). Here, samples were thawed in the dark overnight in a refrigerator at $4{ }^{\circ} \mathrm{C}$ and, once thawed, salinity was measured to nearest 0.01 using a salinometer YSI Pro Plus (YSI ProQuatro I Portable Multiparameter Water Quality Meter). Bulk salinity and temperatures were applied for calculating brine and gas volumes of the ice following [26]. More details on sampling procedures are found in $[4,25]$.

\subsection{CTD, Chlorophyll a, Suspended Particulate Matter}

Water samples for $\mathrm{Chl} a$ and SPM were sampled using a bilge pump with an intake immersed through a $9.0 \mathrm{~cm}$ drilled hole in the ice to a depth of $1.5 \mathrm{~m}$ below bottom of the sea ice. Chl $a$ in water samples and thawed ice were determined by filtering $200 \mathrm{~mL}$ of the sample through glass fibre filters (GF75, Advantec). Filters with phytoplankton were extracted in $10 \mathrm{~mL} \mathrm{95 \%} \mathrm{ethanol} \mathrm{for} \mathrm{about} 16 \mathrm{~h}$, and the extract was centrifuged and the supernatant was analysed on a Turner Trilogy fluorometer (Trilogy Laboratory 
Fluorometer | Turner Designs | United States). SPM concentrations were determined by filtration of an exact volume (0.5-1.1) of water through pre-combusted $\left(400{ }^{\circ} \mathrm{C}, 6 \mathrm{~h}\right)$ glass fiber filters (GF/F, Whatman). Distilled water was used to remove any salt residues, and filters were kept dark and cold until returned to Denmark where they were dried $\left(60{ }^{\circ} \mathrm{C}, 16 \mathrm{~h}\right)$ and weighed. More details on laboratory procedures are given in [23]. CDOM absorption coefficients in the sea ice sampled near the present site in 2011 were low and absorption signal was close to detection limit of the spectrophotometer method and not included here (Lund-Hansen, unpublished data). On 10 March in 2008, a Seabird CTD SBE 19plus (SBE 19plus V2 SeaCAT Profiler CTD I Sea-Bird Scientific-Overview I Sea-Bird) mounted with a Seapoint fluorometer and a Wetlabs C-Star transmissometer (C-Star Transmissometer | Sea-Bird Scientific-Overview | Sea-Bird) was applied to measure phytoplankton and SPM concentrations and distributions with depths in the water column below the ice. Water samples for Chl $a$ and SPM were collected with a Niskin $5 \mathrm{~L}$ water sampler from $1.5 \mathrm{~m}$ below the sea ice, and Chl $a$ and SPM samples were analysed as described above. The March 2008 calibrations of fluorometer signal against Chl $a$ concentrations and transmissometer signal against SPM concentrations were verified with the March 2013 samples of Chl $a$ and SPM.

\subsection{Data Treatment}

The vertically resolved spectrally upwelling and downwelling data $\left(\mathrm{mW} \mathrm{m}^{-2} \mathrm{~nm}^{-1}\right)$ were all integrated into PAR ( $\mu \mathrm{mol}$ photons $\mathrm{m}^{-2} \mathrm{~s}^{-1}$ ) following standard methods [19]. Diffuse attenuation coefficient $K_{d}(P A R)$ was determined by linear regression between natural logarithm $(\mathrm{ln})$ transformed PAR readings and depth using the Lambert-Beer law where irradiance at the depth $\mathrm{z}\left(\mathrm{I}_{\mathrm{z}}\right)$ equals: $\mathrm{I}_{\mathrm{z}}=\mathrm{I}_{\mathrm{O}} \times \mathrm{e}^{-\mathrm{Kd}(\mathrm{PAR}) \times \mathrm{z}} . \mathrm{I}_{\mathrm{O}}$ is irradiance at the ice-water surface and $\mathrm{K}_{\mathrm{d}}(\mathrm{PAR})$ is the diffuse attenuation coefficient for downwelling PAR, as outlined [23]. The equations of the regression lines $\left(r^{2}>0.99\right)$ between depth and $\ln (\mathrm{PAR})$ were all statistically significant $(p<0.01)$ and applied to derive PAR irradiances at the bottom of the ice $\left(\mathrm{I}_{\mathrm{O}}\right)$, as described by [23]. Spectral measurements were accomplished within an hour around noon on 14 March. Integrated PAR data at depths based on the spectrally resolved upwelling and downwelling measurements, were corrected for any changes in downwelling PAR at the surface which was measured continiuosly between 12 and 19 March at the nearby upwelling and downwelling PAR site (Figure 1b).

\subsection{PAR Partitioning}

Diffuse attenuation coefficient $\mathrm{K}_{\mathrm{d}}(\mathrm{PAR})$ is expressed as the sum of partial attenuation coefficients related to water, chromophoric dissolved organic matter (CDOM), phytoplankton, and SPM as [19]:

$$
\mathrm{K}_{\mathrm{d}}(\mathrm{PAR})=\mathrm{K}_{\mathrm{w}}+\mathrm{K}_{\mathrm{CDOM}}+\mathrm{K}_{\text {Phyto }}+\mathrm{K}_{\mathrm{SPM}}
$$

or as:

$$
\mathrm{K}_{\mathrm{d}}(\mathrm{PAR})=0.027+\mathrm{K}^{*} \mathrm{CDOM}\left(\mathrm{CDOM}_{440}\right)+\mathrm{K}_{\text {Phyto }}^{*}(\mathrm{Chl} a)+\mathrm{K}^{*} \mathrm{SPM}(\mathrm{SPM})
$$

where $0.027 \mathrm{~m}^{-1}$ is PAR attenuation in pure water [27], $\mathrm{K}^{*} \mathrm{CDOM}$ is the CDOM specific attenuation coefficient of $0.22 \mathrm{~m}^{2} \mathrm{~g}^{-1} \mathrm{CDOM}$ [28], $\mathrm{K}^{*}$ Phyto $(\mathrm{Chl} a)$, and $\mathrm{K}^{*} \mathrm{SPM}(\mathrm{SPM})$ are specific attenuation coefficients of phytoplankton equal to $0.029 \mathrm{~m}^{2} \mathrm{mg}^{-1}$ and $0.13 \mathrm{~m}^{2} \mathrm{~g}^{-1}$ for SPM obtained from a comparable study [23]. CDOM absorption coefficient at $440 \mathrm{~nm}$ was derived as described [23] based on water samples collected at the site in March 2008 (Lund-Hansen, unpublished data).

\section{Results}

\subsection{Physical and Optical Properties of the Snow, Ice, and Water Column}

The average ice thickness was $74.8 \pm 0.8 \mathrm{~cm}$ and average snow depth was $1.2 \mathrm{~cm} \pm 0.2 \mathrm{~cm}$. The ice was relatively cold at the surface, as low as $-8.9{ }^{\circ} \mathrm{C}$, but tem- 
perature increased gradually to $-2.0^{\circ} \mathrm{C}$ at the sea ice-water interface, with only small variations in bulk salinity (Figure 2a). Gas and brine volumes (\%) increased towards the bottom of the ice with the increase in ice temperature [26] (Figure 2b), and Chl $a$ increased similarly towards the sea-ice water interface (Figure 2c).
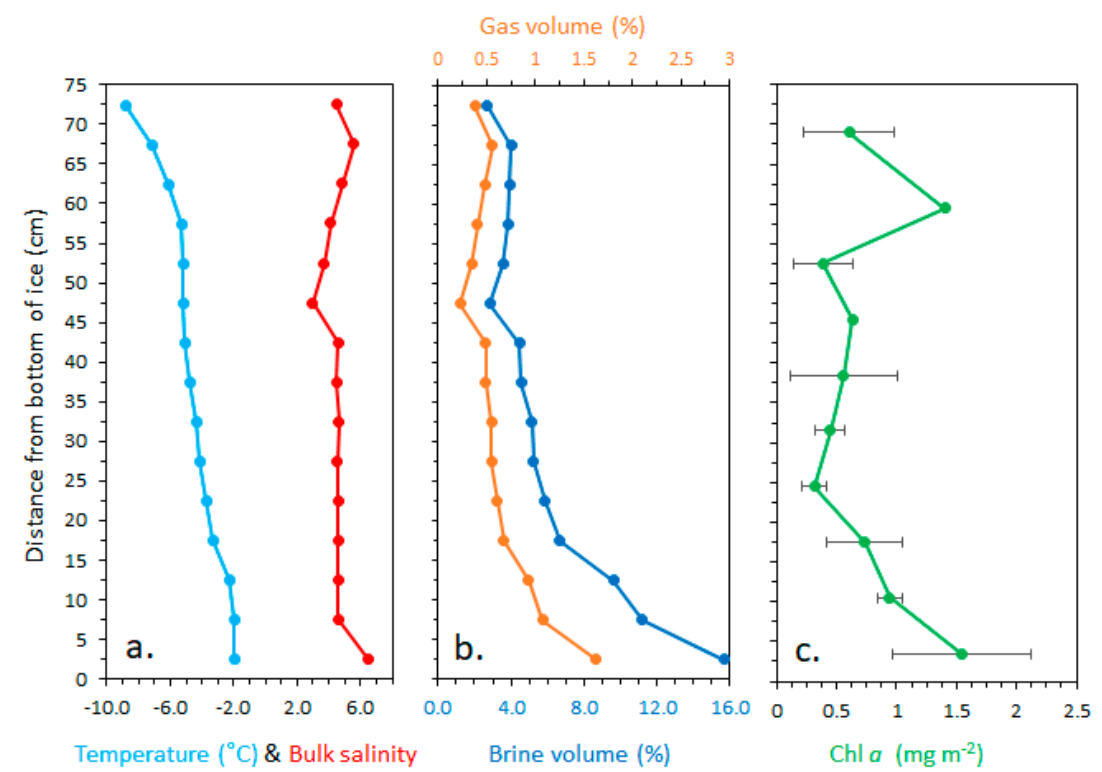

Figure 2. Ice temperature and bulk salinity and (a), brine and gas volumes (b), and chlorophyll $a$ (c).

Below ice water temperatures varied between $-1{ }^{\circ} \mathrm{C}$ and $-0.5{ }^{\circ} \mathrm{C}$ and salinity between 21.7 and 23, with peaks in salinity likely related to double diffusion [29], but there was no stratification of the water column (Figure 3a). Similarly for the optical constituents $\mathrm{Chl} a$ and SPM, there were likewise no variations with depth, with a Chl $a$ of about $0.65 \mu \mathrm{g} \mathrm{L}{ }^{-1}$ in the entire water column and SPM concentrations between 1.2 and $1.5 \mathrm{mg} \mathrm{L}^{-1}$ (Figure $3 \mathrm{~b}$ ).
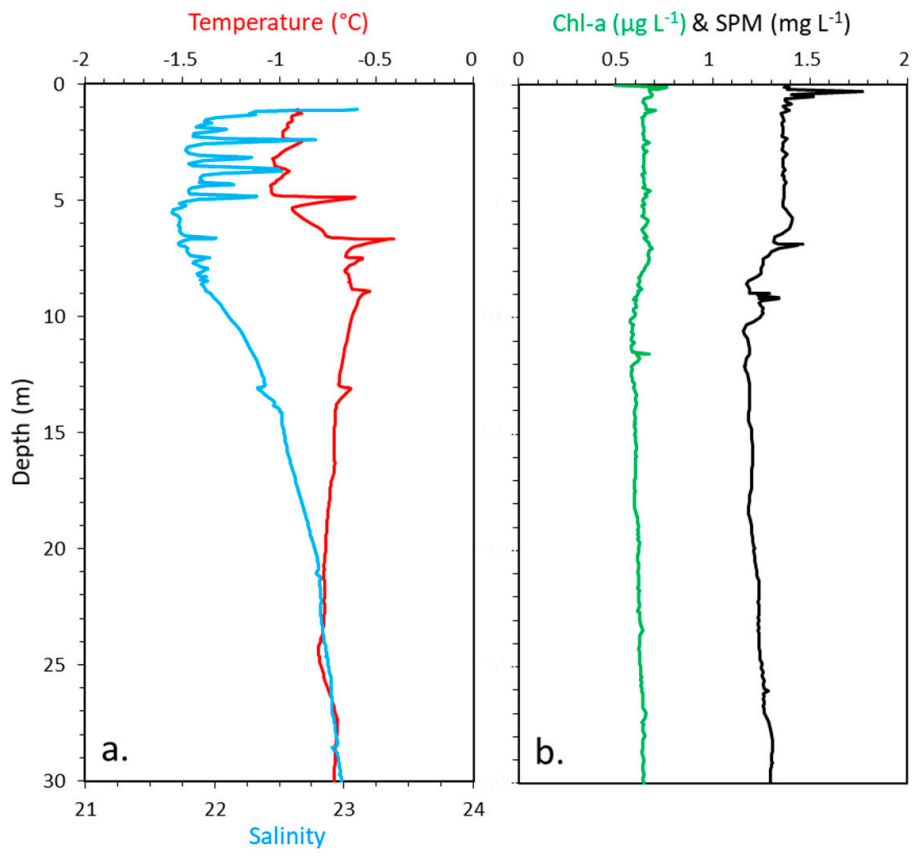

Figure 3. Under-ice profiles of salinity and temperature (a) chlorophyll $a$ and suspended particulate matter (b). Data were obtained on 10 March 2008 at the present site in Kangerlussuaq and calibrations were verified with 2013 measured chlorophyll a and suspended particulate matter concentrations as outlined above (Section 2.3). 


\subsection{Upwelling and Downwelling PAR}

Extension of the $\ln (\mathrm{PAR})$ regression lines towards the sea-ice water interface gave a downwelling irradiance of $46.8 \mu \mathrm{mol}$ photons $\mathrm{m}^{-2} \mathrm{~s}^{-1}$ with snow and $105.9 \mu \mathrm{mol}$ photons $\mathrm{m}^{-2} \mathrm{~s}^{-1}$ without snow. Upwelling PAR at the interface reached $5.1 \mu \mathrm{mol}$ photons $\mathrm{m}^{-2} \mathrm{~s}^{-1}$ with snow and $8.2 \mu \mathrm{mol}$ photons $\mathrm{m}^{-2} \mathrm{~s}^{-1}$ without snow (Figure 4) This equals PAR irradiance reflectances of $11 \%$ and $8 \%$ as the ratio between upwelling and downwelling PAR [19] with and without snow. Results showed that both $K_{d}(P A R)$ and $K_{u}(P A R)$ were slightly higher without any snow, but also that $K_{d}(P A R)$ was higher than $\mathrm{K}_{\mathrm{u}}(\mathrm{PAR})$ independent of snow cover as summarized in Table 1.

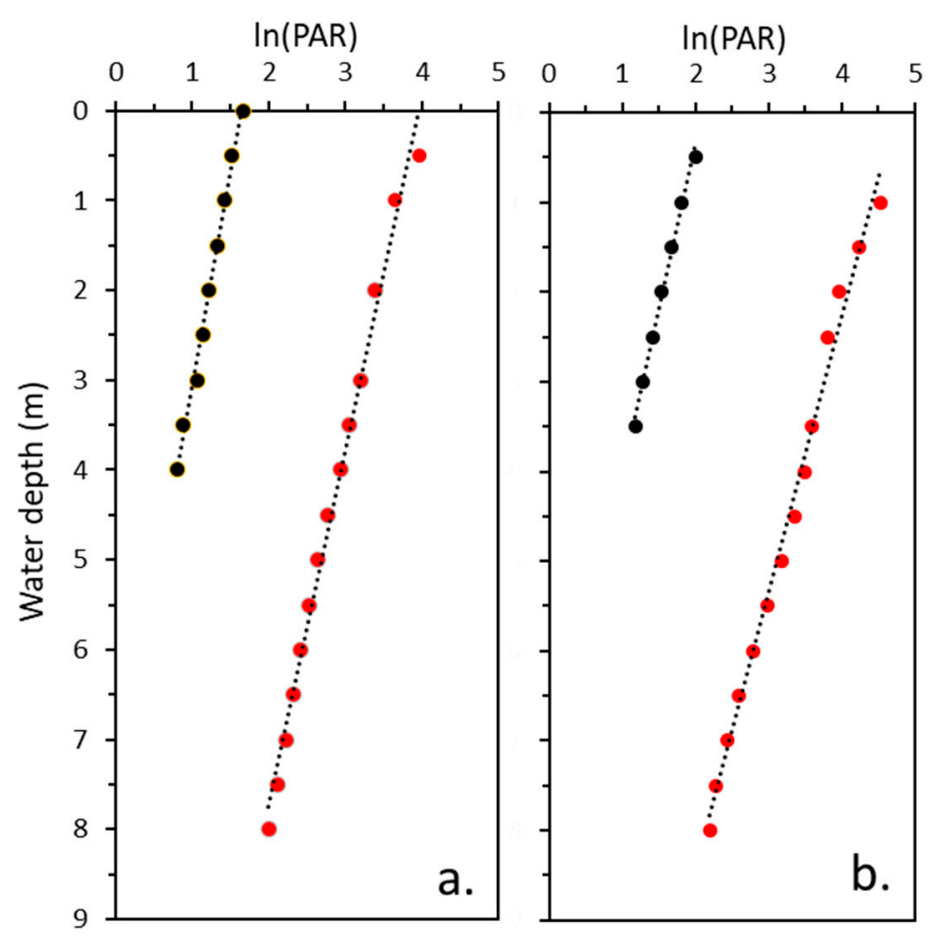

Figure 4. The $\ln (\mathrm{PAR})$ for downwelling $(\bullet)$ and upwelling $(\bullet)$ PAR versus depth below the sea ice with (a) and without (b) a snow cover.

Table 1. Diffuse attenuation coefficients for downwelling PAR $-K_{d}(P A R)$ and upwelling PAR $\mathrm{K}_{\mathrm{u}}(\mathrm{PAR})$, under-ice downwelling PAR $\left(\mathrm{I}_{\mathrm{Od}}\right)$, and under-ice upwelling PAR $\left(\mathrm{I}_{0 \mathrm{u}}\right)$, irradiance reflectances with (+Snow) and without snow (-Snow). Average downwelling surface PAR during sampling period was $546.4 \mu \mathrm{mol}$ photons $\mathrm{m}^{-2} \mathrm{~s}^{-1}$.

\begin{tabular}{ccc}
\hline & +Snow & - Snow \\
\hline $\mathrm{K}_{\mathrm{d}}(\mathrm{PAR}) \mathrm{m}^{-1}$ & 0.25 & 0.32 \\
\hline $\mathrm{K}_{\mathrm{u}}(\mathrm{PAR}) \mathrm{m}^{-1}$ & 0.21 & 0.27 \\
\hline $\mathrm{I}_{0 \mathrm{~d}}($ Down $) \mu \mathrm{mol}$ photons $\mathrm{m}^{-2} \mathrm{~s}^{-1}$ & 46.8 & 105.9 \\
\hline $\mathrm{I}_{0 \mathrm{u}}(\mathrm{Up}) \mu \mathrm{mol}$ photons $\mathrm{m}^{-2} \mathrm{~s}^{-1}$ & 5.1 & 8.2 \\
\hline Irradiance reflectance $(\%)$ & 11 & 8 \\
\hline
\end{tabular}

\subsection{Partitioning}

Partitioning results clearly demonstrated that PAR attenuation (72\%) was related to SPM as summarized in Table 2, and much less to phytoplankton (11\%) and water (10\%). 
Table 2. Partitioning (\%) of $\mathrm{K}_{\mathrm{d}}(\mathrm{PAR})$ relative to the optical constituents-water, CDOM, phytoplankton, and suspended particulate matter.

\begin{tabular}{ccccc}
\hline & Water & CDOM & Phyto & SPM \\
\hline $\mathrm{K}_{\mathrm{d}}(\mathrm{PAR})(\%)$ & 10 & 7 & 11 & 72 \\
\hline
\end{tabular}

\subsection{Spectral Distribution}

Spectral distributions of both upwelling and downwelling irradiances with and without a snow cover were different and irradiances around $500 \mathrm{~nm}$ the least attenuated wavelengths in both cases (Figure 5a). A comparison of spectral distributions of ratios between upwelling and downwelling with no snow $\left(E_{u}-/ E_{d}-\right)$ and with snow $\left(E_{u}+/ E_{d}+\right)$ showed, that UV-A and blue (320-480 nm), and especially red (600-700 nm) and near infrared $(750-820 \mathrm{~nm}$ ) wavelengths were relatively stronger attenuated with a snow cover (Figure 5b). Integration of irradiances between 320 and $400 \mathrm{~nm}$ to derive UV-A irradiance $\left(\mathrm{W} \mathrm{m}^{-2}\right)$ showed that $\mathrm{E}_{\mathrm{d}}(\mathrm{UV}-\mathrm{A})$ increased from 1.5 to $3.4 \mathrm{~W} \mathrm{~m}^{-2}$ without snow and that $\mathrm{E}_{\mathrm{u}}(\mathrm{UV}-\mathrm{A})$ increased from 0.08 to $0.24 \mathrm{~W} \mathrm{~m}^{-2}$ giving ratios of 2.3 and 3.0, respectively.
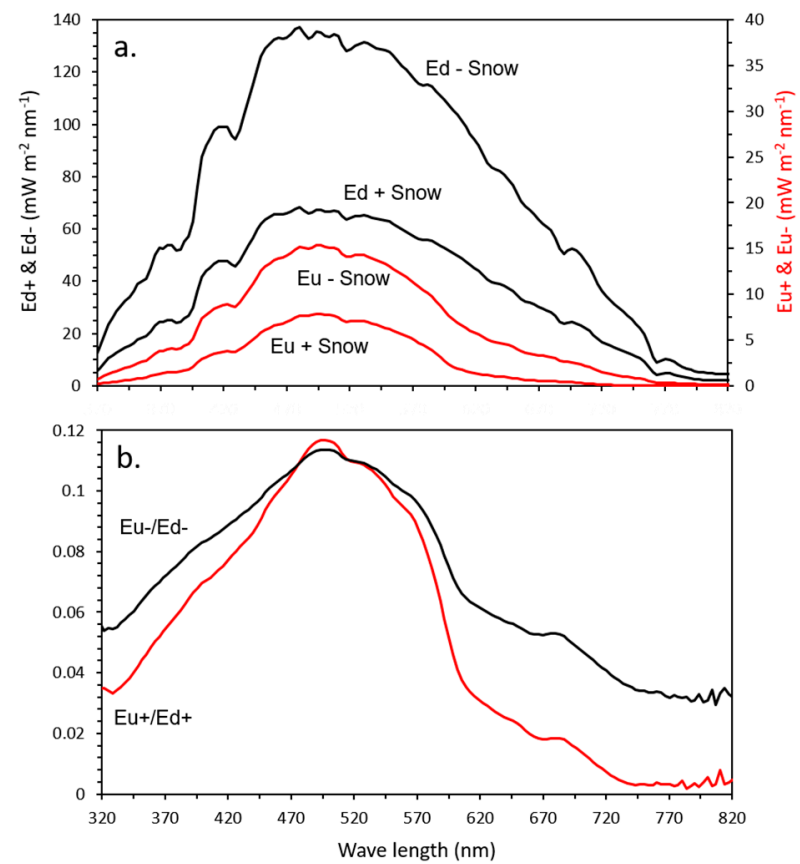

Figure 5. Spectral distribution of downwelling irradiance $3 \mathrm{~cm}$ below the ice bottom without snowcover $($ Ed - Snow), with a snow cover (Ed + Snow), upwelling without snow cover $(\mathrm{Eu}-\mathrm{Snow})$, and upwelling with a snow cover $(\mathrm{Eu}+\mathrm{Snow})(\mathrm{a})$ and spectral distribution of the ratio between upwelling and downwelling irradiance without snow cover $(\mathrm{Eu}-/ \mathrm{Ed}-)$ and with a snow cover $(\mathrm{Eu}+/ \mathrm{Ed}+)(\mathbf{b})$.

\subsection{Time-Series of Downwelling, Under-Ice, and Upwelling PAR}

The daily maximum of under-ice PAR varied between 40 and $60 \mu \mathrm{mol}$ photons $\mathrm{m}^{-2} \mathrm{~s}^{-1}$ with the initial snow cover of $1 \mathrm{~cm}$, which melted and disappeared during 15-16 March where air temperatures at the site increased from $-12{ }^{\circ} \mathrm{C}$ to $+0{ }^{\circ} \mathrm{C}$ during 1.5 day, after which under-ice PAR reached a daily maximum of $180 \mu \mathrm{mol}$ photons $\mathrm{m}^{-2} \mathrm{~s}^{-1}$ during 17-19 March (Figure 6b). The nearly threefold higher under-ice PAR was clearly related to the melting of the snow cover and strongly reduced PAR albedo from 0.75 between 12 and 15 March to 0.27 between 17 and 19 March, and a parallel increase in transmittance from 0.08 to 0.23 . Upwelling PAR for the experimental period 12-19 March was calculated by adding $10 \%$ to measured under-ice PAR, where maximum daily upwelling under-ice PAR reached about $4 \mu \mathrm{mol}$ photons $\mathrm{m}^{-2} \mathrm{~s}^{-1}$ with snow cover, which increased to about $16 \mu \mathrm{mol}$ photons $\mathrm{m}^{-2} \mathrm{~s}^{-1}$ after melting of the snow (Figure $6 \mathrm{~b}$ ). 

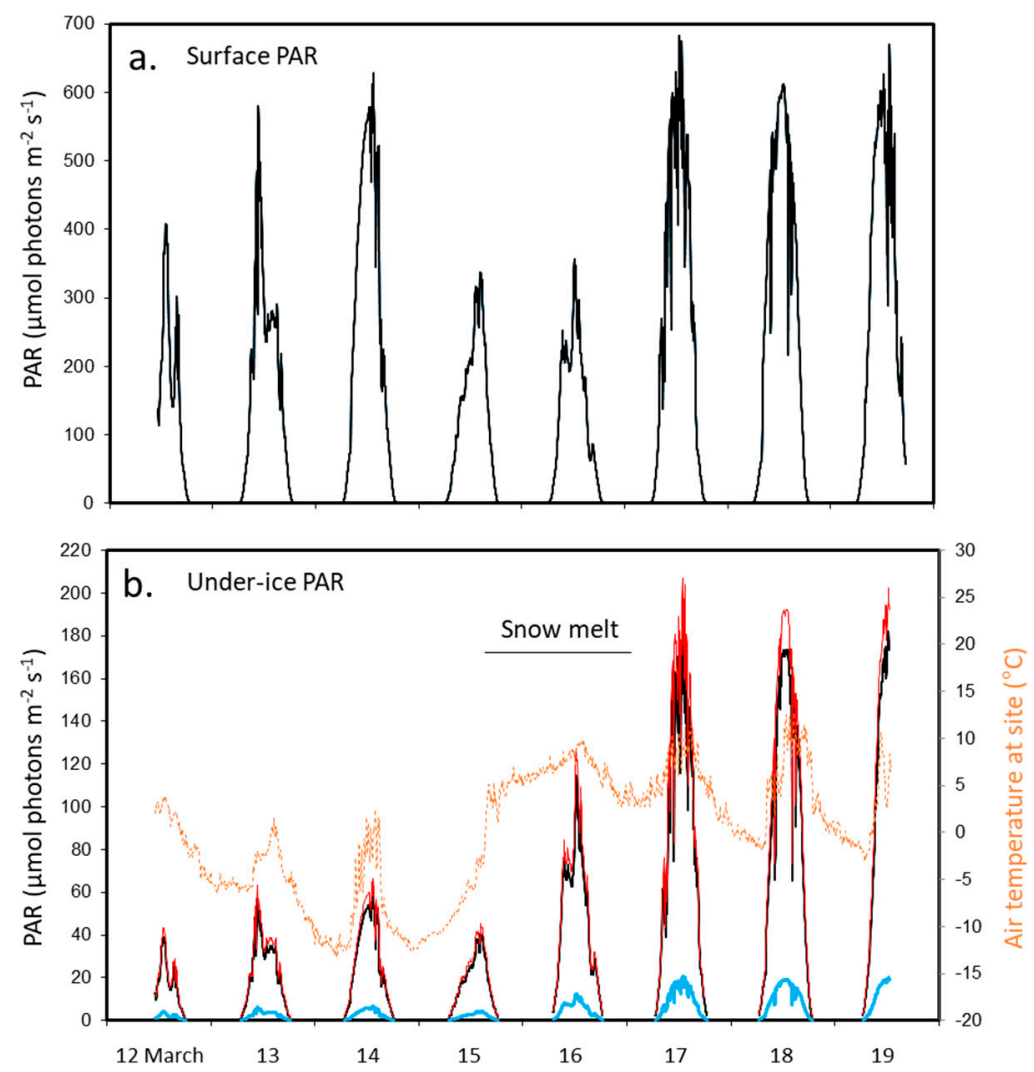

Figure 6. Surface downwelling PAR (a), and under-ice PAR between 12 and 19 March (black full line), 10\% upwelling PAR (blue full line), the sum of upwelling and downwelling (red full line), and air temperature at $1.0 \mathrm{~m}$ above the surface (dotted orange line) (b), with snow melt period indicated.

\section{Discussion}

\subsection{Spectral Distribution and $K_{d}(P A R)$}

The present spectral distribution data for under-ice irradiances were comparable to previous under-ice observations also with comparatively higher absorption in the red part of the spectrum with a snow cover, and minimum attenuation at about $500 \mathrm{~nm}$ [8]. Spectral composition of downwelling irradiance could be changed by algae absorption in the ice [30], but the present $\mathrm{Chl} a$ concentrations are low with an average of $0.75 \mathrm{mgChl} a \mathrm{~m}^{-2}$ for the whole ice core, which is unlikely to affect the composition, as observed in other studies with bottom ice Chl $a$ of 20-60 $\mathrm{mg} \mathrm{Chl} a \mathrm{~m}^{-2}$ [31]. Such low Chl $a$ concentration in the ice or at the bottom of the ice aligns with previous studies in Kangerlussuaq [8,24]. The present higher absorption of red light emphasizes the optical effects of even a $1 \mathrm{~cm}$ thick snow cover, accentuated by a doubling from $67.4 \mathrm{~mW} \mathrm{~m}^{-2} \mathrm{~nm}^{-1}$ to $133.2 \mathrm{~mW} \mathrm{~m}^{-2} \mathrm{~nm}^{-1}$ at $500 \mathrm{~nm}$ with no snow cover. A relatively higher attenuation in the red part of the spectrum without a snow cover was also observed in a previous study in Kangerlussuaq [8]. The attenuation of upwelling irradiances were relatively higher in the blue and red parts of the spectrum compared to the with snow situation, and UV-A intensities further increased with no snow. The $\mathrm{K}_{\mathrm{d}}(\mathrm{PAR})$ for downwelling PAR was $0.25 \mathrm{~m}^{-1}$ with snow and $0.32 \mathrm{~m}^{-1}$ without snow, were also comparable to previous below-ice coefficients in Kangerlussuaq [24]. However, the present coefficients were nearly two times higher than values of $0.15 \mathrm{~m}^{-1}$ in the high Arctic Young Sound [32] and $0.17 \mathrm{~m}^{-1}$ in the central Arctic Ocean [33]. The twofold higher $\mathrm{K}_{\mathrm{d}}(\mathrm{PAR})$ in Kangerlussuaq is likely related to higher SPM concentrations in Kangerlussuaq where partitioning analyses showed that $72 \%$ of PAR attenuation was related to SPM. The Kangerlussuaq summer study in turbid meltwater showed a significant $(p<0.01)$ and positive linear and high $\left(r^{2}=0.92\right)$ correlation between SPM and $\mathrm{K}_{\mathrm{d}}(\mathrm{PAR})$, and that reflectance was governed by SPM [28]. The inflow of glacial freshwater to Kangerlussuaq ends from beginning September with no other inflow during winter, so the higher $\mathrm{K}_{\mathrm{d}}(\mathrm{PAR})$ 
observed here could be related to resuspension of sediment by the strong tidal currents with tidal ranges up to 2 to $3 \mathrm{~m}$ in Kangerlussuaq [22].

\subsection{Under-Ice Light Field and Reflectances}

The downwelling attenuation coefficient $K_{d}(P A R)=0.25 \mathrm{~m}^{-1}$ with snow was slightly higher without snow $\mathrm{K}_{\mathrm{d}}(\mathrm{PAR})=0.32 \mathrm{~m}^{-1}$, which might be attributed to a changed angular field of downwelling irradiance in the absence of a snow cover [34,35]. However, brine and gas volumes of the present ice were quite high, which strongly enhance the scattering whereby light leaving the ice at the bottom is highly diffused [36]. Spectral measurements were obtained within about $1 \mathrm{~h}$, but it cannot be ruled out that conditions in the water column changed during measurements considering the high tidal ranges of 2 to $3 \mathrm{~m}$ in Kangerlussuaq [22]. A change in condition is substantiated by the fact that $K_{d}(P A R)$ actually increased from 0.25 to $0.32 \mathrm{~m}^{-1}$ during the experiment. There was further a small difference of $0.04 \mathrm{~m}^{-1}$ between $\mathrm{K}_{\mathrm{d}}(\mathrm{PAR})$ and $\mathrm{K}_{\mathrm{u}}(\mathrm{PAR})$ with higher $\mathrm{K}_{\mathrm{d}}(\mathrm{PAR})$ for reasons which are not clear, and calls for further investigation. The PAR upwelling irradiances at the bottom of the sea ice of 5.1 and $8.2 \mu \mathrm{mol}$ photons $\mathrm{m}^{-2} \mathrm{~s}^{-1}$ for downwelling irradiances of 46.8 and $105.9 \mu \mathrm{mol}$ photons $\mathrm{m}^{-2} \mathrm{~s}^{-1}$ with and without snow equaled irradiance reflectances of $11 \%$ and $8 \%$. The under-ice PAR was determined by extension of the regression line $\ln (\mathrm{PAR})$ at depth versus depth to the bottom of the ice, which assumes that PAR attenuation is exponential in the entire water column and the very high $\left(r^{2}=0.99\right)$ correlation coefficients of the regression lines confirmed this. Under-ice PAR data points were corrected for any changes in surface downwelling PAR measured with the continuous PAR sensor so the difference of $3 \%$ point in irradiance reflectance might also relate to changed conditions.

\subsection{Low Light Adaptation}

Active photosynthesis at a PAR level of $0.17 \mu \mathrm{mol}$ photons $\mathrm{m}^{-2} \mathrm{~s}^{-1}$ has recently been observed below a combined pack of $1 \mathrm{~m}$ snow and $0.9 \mathrm{~m}$ thick sea ice [10], and demonstrates that even extremely low PAR irradiance can drive photosynthesis of the highly shade-adapted sea ice algal community. In the present study upwelling irradiances reached 5.1 and $8.2 \mu \mathrm{mol}$ photons $\mathrm{m}^{-2} \mathrm{~s}^{-1}$ for snow-covered and snow-free conditions which added $11 \%$ and $8 \%$ to the under-ice PAR. Total under-ice PAR then reached $51.9 \mu \mathrm{mol}$ photons $\mathrm{m}^{-2} \mathrm{~s}^{-1}$ as 5.1 plus a downwelling of $46.8 \mu \mathrm{mol}$ photons $\mathrm{m}^{-2} \mathrm{~s}^{-1}$ for a situation with a snow cover and a total of $105.9 \mu \mathrm{mol}$ photons $\mathrm{m}^{-2} \mathrm{~s}^{-1}$ with no snow (Table 1). Ice algae primary production is generally assumed to be light limited $[37,38]$ where this higher-downwelling PAR plus upwelling — could potentially increase the primary production, but this is out of the scope of the present study.

\subsection{Acclimation to Low Light, Snow Melt, and Removal}

Light passes through a pack of snow and ice where albedo, high scattering and absorption coefficients in the pack ensure very low light intensities at the bottom of the sea ice. Light attenuation is much stronger in snow [14] compared to ice, giving typical attenuation coefficients of $11.9 \mathrm{~m}^{-1}$ in snow and $0.84 \mathrm{~m}^{-1}$ in ice [14]. Furthermore, snow is a much more dynamic entity compared to the thickness of even land-fast ice and occurrences with periods of melt, snowfall and snowdrift $[39,40]$ and is accordingly the dominant factor in governing the under-ice light intensities [14]. For instance, under-ice light intensities increased in the present study from about 40 to $180 \mu \mathrm{mol}$ photons $\mathrm{m}^{-2} \mathrm{~s}^{-1}$ within 1.5 days related to a melt of the snow cover. The photobiological and photophysiological effects of the PAR increase and the consequences have been documented in a parallel study from this campaign [25] and are just summarized in brief here. A comparison of conditions before and after the melt and increase in under-ice PAR showed that algae biomass (Chl $a$ ) decreased 3.6 times, DOC 1.9 times, the photobiological parameters rETR max $_{\text {axd }}$ an $\Phi_{\text {PSI_max }}$ were both reduced, and species composition changed from being dominated by flagellates (55\%) to diatoms (67\%) after the melt [25]. In a follow-up study in Kangerlussuaq in 2016 under-ice PAR increased from 60 to $150 \mu \mathrm{mol}$ photons $\mathrm{m}^{-2} \mathrm{~s}^{-1}$ by artificial re- 
moval of the snow cover, whereby $\mathrm{rETR}_{\max }$ and $\Phi_{\text {PSII_max }}$ were also reduced, along with development of photoprotective pigments and mycosporine-like amino acids (MAAs) for UV-protection [38]. Potential effects on the photobiology of the ice algae are assumed low at low downwelling irradiances, but clearly adds to the total irradiance experienced by the algae at high downwelling irradiances.

\subsection{Light Saturation Point $E_{k}$}

$E_{\mathrm{k}}$ is the light intensity at which photosynthesis begins to shift from light limitation to limitation by carboxylation. Above this light intensity, photoinhibition can potentially commence for any given assemblage of microalgae due to excess photons that cannot be used for carbon fixation [37]. $E_{\mathrm{k}}$ reached $45 \mu \mathrm{mol}$ photons $\mathrm{m}^{-2} \mathrm{~s}^{-1}$ in the parallel study [25], which aligns with the under-ice PAR before the snow melt of 40-50 $\mu \mathrm{mol}$ photons $\mathrm{m}^{-2} \mathrm{~s}^{-1}$. This $E_{\mathrm{k}}$ value was greatly exceeded for a maximum downwelling underice PAR of $180 \mu \mathrm{mol}$ photons $\mathrm{m}^{-2} \mathrm{~s}^{-1}$ after the melt, though irradiance actually encountered by the ice algae reached $198 \mu \mathrm{mol}$ photons $\mathrm{m}^{-2} \mathrm{~s}^{-1}$ with the added $10 \%$ upwelling. This 4 times higher irradiance, relative to an $E_{\mathrm{K}}$ of $45 \mu \mathrm{mol}$ photons $\mathrm{m}^{-2} \mathrm{~s}^{-1}$, caused strong photoinhibition, damaging photobiological effects, and changes in biomass and species composition before and after the melt as shown in the study [25]. It should be emphasized that $E_{\mathrm{k}}$ is not constant but varies depending on the light history of the algae, nutrients, and their species composition. For instance, an $E_{\mathrm{k}}$ around $120 \mu \mathrm{mol}$ photons $\mathrm{m}^{-2} \mathrm{~s}^{-1}$ was obtained in another Kangerlussuaq study where artificial removal of the snow cover increased under-ice PAR to near $150 \mu \mathrm{mol}$ photons $\mathrm{m}^{-2} \mathrm{~s}^{-1}$, which also had some adverse and damaging effects [38]. A laboratory study with a low $E_{\mathrm{k}}$ of $25 \mu \mathrm{mol}$ photons $\mathrm{m}^{-2} \mathrm{~s}^{-1}$ also showed clear photoinhibition once irradiances $>E_{\mathrm{k}}$ [40]. When ice algae are adapted to a certain level of irradiance, as characterized by $E_{\mathrm{k}}$, photoinhibition can commence and photodamaging effects can occur at irradiances higher than $E_{\mathrm{k}}$, where a $10 \%$ added PAR upwelling might add to these effects.

\section{Conclusions}

Spectral distributions, PAR intensities, and optical properties of upwelling and downwelling irradiances below sea ice have been explored in a study on first-year land-fast sea ice. The study showed that upwelling PAR reached about $10 \%$ of downwelling intensities. The upwelling was related to scattering in the water column, where partitioning analyses showed high SPM related scattering coefficients. Data from a parallel and similar studies carried out at the site in Kangerlussuaq, showed that removal of a snow cover by melt or artificially removed strongly affected photobiology of the ice algae by a significant increase in under-ice PAR. When under-ice irradiances $>E_{\mathrm{k}}$ it was assumed that the $10 \%$ upwelling irradiances added to the photoinhibition and adverse effects of the increased PAR.

Author Contributions: Conceptualization, All authors contributed equally to the design of the experiment. M.B.-N.; mainly responsible for sampling, laboratory analyses, and data analyses in a preliminary report, L.C.L.-H., I.H., B.K.S. and T.S.; wrote the manuscript and all authors contributed by discussing and improving the paper. All authors have read and agreed to the published version of the manuscript.

Funding: This project was funded by the Danish Council for Independent Research (Project DFF-1323-00335: Sea ice ecosystems: Ecological effects of a thinning snow cover), the New Zealand Min-istry of Business, Innovation and Employment (Project ANTA1801), the Carlsberg Foundation, Aar-hus University, and the Hartmann Brothers Foundation and was developed in the frame of the pro-ject FACE-IT (The Future of Arctic Coastal Ecosystems-Identifying Transitions in Fjord Systems and Adjacent Coastal Areas). FACE-IT has received funding from the European Union's Horizon 2020 research and innovation program under grant agreement No 869154.

Institutional Review Board Statement: Not applicable.

Informed Consent Statement: Not applicable.

Data Availability Statement: Data are available from authors pending reasonable requests. 
Acknowledgments: We are grateful to the staff of Kangerlussuaq International Science Support for logistical assistance and kind hospitality in Greenland. This is a contribution to the Arctic Science Partnership (ASP) asp-net.org.

Conflicts of Interest: The authors declare no conflict of interest.

\section{References}

1. Parkinson, C.L. Spatially mapped reductions in the length of the Arctic sea ice season. Geophys. Res. Lett. 2014, 41, 4316-4322. [CrossRef]

2. Parkinson, C.L. A 40-y record reveals gradual Antarctic sea ice increases followed by decreases at rates far exceeding the rates see in the Arctic. Proc. Natl. Acad. Sci. USA 2019, 116, 14414-14423. [CrossRef]

3. Thackeray, C.W.; Hall, A. An emergent constraint on future Arctic sea-ice albedo feedback. Nat. Clim. Chang. 2019, 9, 972-978. [CrossRef]

4. Lund-Hansen, L.C.; Søgaard, D.H.; Sorrell, B.K.; Gradinger, R.; Meiners, K.M. Arctic Sea Ice Ecology-Seasonal Dynamics in Algal and Bacterial Productivity; Springer: Berlin, Germany, 2020; 178p. Available online: https://www.springer.com/gp/book/9783030374716 (accessed on 30 July 2021).

5. Kolbach, D.; Schaafsma, F.L.; Graeve, M.; Lebreton, B.; Lange, B.A.; David, C.; Vortkamp, M.; Flores, H. Strong linkage of polar cod (Boreogadus saida) to sea ice algae-produced carbon: Evidence from stomach content, fatty acid and stable isotope analyses. Prog. Oceanogr. 2017, 152, 62-74. [CrossRef]

6. Arrigo, K. Sea ice as a habitat for primary producers. In Sea Ice, 3rd ed.; Thomas, D.N., Ed.; Wiley Blackwell: Oxford, UK, 2017; 652p.

7. Ehn, J.; Mundy, C.J. Assessment of light absorption within highly scattering bottom sea ice from under-ice light measurements: Implications for Arctic ice algae primary production. Limnol. Oceanogr. 2013, 58, 893-902. [CrossRef]

8. Lund-Hansen, L.C.; Hawes, I.; Sorrell, B.K.; Nielsen, M.H. Removal of snow cover inhibits spring growth of Arctic ice algae through physiological and behavioral effects. Polar Biol. 2013, 37, 471-481. [CrossRef]

9. Campbell, K.; Mundy, C.J.; Belzile, C.; Delaforge, A.; Rysgaard, S. Seasonal dynamics of algal and bacterial communities in Arctic sea ice under variable snow cover. Polar Biol. 2018, 41, 1869-1896. [CrossRef]

10. Hancke, K.; Lund-Hansen, L.C.; Pedersen, S.; King, M.d.; Andersen, P.; Sorrell, B.K. Extreme low light requirement for algae growth underneath sea ice: A case study from Station Nord, NE Greenland. J. Geophys. Res. Oceans 2018, 123, 985-1000. [CrossRef]

11. Terrado, R.; Lovejoy, C.; Massana, R.; Vincent, W. Microbial food web responses to light and nutrients beneath the coastal Arctic Ocean sea ice during the winter-spring transition. J. Mar. Syst. 2008, 74, 964-977. [CrossRef]

12. Light, B.; Grenfell, T.; Perovich, D. Transmission and absorption of solar radiation by Arctic sea ice during the melt season. $J$. Geophys. Res. Oceans 2008, 113, C03023. [CrossRef]

13. Hamre, B.; Winther, J.; Gerland, S.; Stamnes, J.; Stamnes, K. Modeled and measured optical transmittance of snow-covered first-year sea ice in Kongsfjorden, Svalbard. J. Geophys. Res. Oceans 2004, 109, C10006. [CrossRef]

14. Perovich, D. Sea ice and sunlight. In Sea Ice, 3rd ed.; Thomas, D.N., Ed.; Wiley Blackwell: Oxford, UK, 2017; 652p.

15. Matsuoka, A.; Huot, Y.; Shimada, K.; Saitoh, S.; Babin, M. Bio-optical characteristics of the western Arctic Ocean: Implications for ocean color algorithms. Can. J. Remote Sens. 2007, 33, 503-518. [CrossRef]

16. Doxaran, D.; Ehn, J.; Bélanger, S.; Matsuoka, A.; Hooker, S.; Babin, M. Optical characterisation of suspended particles in the Mackenzie River plume (Canadian Arctic Ocean) and implications for ocean colour remote sensing. Biogeosciences 2012, 9, 3213-3229. [CrossRef]

17. Bélanger, S.; Babin, M. Impact of sea ice on the retrieval of water-leaving reflectance, chlorophyll a concentration and inherent optical properties from satellite ocean color data. Remote Sens. Environ. 2007, 111, 51-68. [CrossRef]

18. Tang, S.; Larouche, P.; Niemi, A.; Michel, C. Regional algorithms for remote-sensing estimates of total suspended matter in the Beaufort Sea. Int. J. Remote Sens. 2013, 34, 6562-6576. [CrossRef]

19. Kirk, J.T.O. Light and Photosynthesis in the Aquatic Ecosystems; Cambridge University Press: Cambridge, UK, 1994; 509p.

20. Ralph, P.J.; Gademann, R. Rapid light curves: A powerful tool to assess photosynthetic activity. Aquat. Bot. 2005, 82, $222-237$. [CrossRef]

21. Mernild, S.; Hasholt, B. Observed runoff, jökulhlaups and suspended sediment load from the Greenland ice sheet at Kangerlussuaq, West Greenland, 2007 and 2008. J. Glaciol. 2009, 55, 855-858. [CrossRef]

22. Nielsen, M.H.; Erbs-Hansen, D.; Knudsen, K.L. Water masses in Kangerlussuaq, a large fjord in West Greenland: The processes of formation and the associated foraminiferal fauna. Polar Res. 2010, 29, 159-175. [CrossRef]

23. Lund-Hansen, L.C. Diffuse attenuation coefficients Kd(PAR) at the estuarine Nort Sea-Baltic Ses transition: Time-series, partitioning, absorption, and scattering. Estuar. Coast. Shelf Sci. 2004, 61, 251-259. [CrossRef]

24. Lund-Hansen., L.C.; Hawes, I.; Nielsen, M.H.; Dahllöf, I.; Sorrell, B. Summer meltwater and spring sea ice primary production, light climate and nutrients in an Arctic estuary, Kangerlussuaq, west Greenland. Arc. Ant. Alp. Res. 2018, 50, e1414468. [CrossRef]

25. Sorrell, B.K.; Hawes, I.; Stratmann, T.; Lund-Hansen, L.C. Photobiological effects on ice algae of a rapid whole-fjord loss of snow cover during spring growth in Kangerlussuaq, a West Greenland Fjord. J. Mar. Sci. Eng. 2021, 9, 814. [CrossRef]

26. Cox, G.F.N.; Weeks, W.F. Equations for determining the gas and brine volumes in sea-ice samples. J. Glaciol. 1983, 102, 306-316. [CrossRef] 
27. Smith, R.; Baker, K. Optical properties of the clearest natural waters (200-800 nm). App. Opt. 1981, 20, 177-184. [CrossRef] [PubMed]

28. Lund-Hansen, L.C.; Andersen, T.J.; Nielsen, M.H.; Pejrup, M. Suspended matter, Chl-a, CDOM, grain sizes, and optical properties in the Arctic fjord-type estuary, Kangerlussuaq, West Greenland durung summer. Estuaries Coasts 2010, 33, 1442-1451. [CrossRef]

29. Sirevaag, A. Turbulent exchange coefficients for the ice/ocean interface in case of rapid melting. Geophys. Res. Let. 2009, 36, GL036587(1-5). [CrossRef]

30. Legendre, L.; Gosselin, M. In situ spectroradiometric estimation of microalgal biomass in first-year sea ice. Polar Biol. 1991, 4, 113-115. [CrossRef]

31. Forrest, A.; Lund-Hansen, L.C.; Sorrell, B.K.; Bowden-Flyod, I.; Lucieer, V.; Cossu, R.; Lange, B.; Hawes, I. Exploring spatial heterogeneity of antarctic sea ice algae using an autonomous underwater vehicle mounted irradiance sensor. Front. Earth Sci. 2019, 7, 1-9. [CrossRef]

32. Søgaard, D.; Sorrell, B.K.; Sejr, M.; Andersen, P.; Rysgaard, S.; Hansen, P.J.; Skyttä, A.; Lemcke, S.; Lund-Hansen, L.C. An under-ice bloom of mixotrophic haptophytes in low nutrient and freshwater-influenced Arctic waters. Sci. Rep. 2021, 11, 2915. [CrossRef] [PubMed]

33. Lund-Hansen, L.C.; Markager, S.; Hancke, K.; Stratmann, T.; Rysgaard, S.; Ramløv, H.; Sorrell, B. Effects of sea-ice light attenuation and CDOM absorption in the water below the Eurasian sector of central Arctic Ocean $\left(>88^{\circ} \mathrm{N}\right)$. Polar Res. 2015, 34, 1-12. [CrossRef]

34. Laney, S.; Krishfield, R.; Toole, J.; Hammar, T.; Ashjian, C. Assessing algal biomass and bio-optical distributions in perennially ice-covered polar ocean ecosystems. Polar Sci. 2014, 8, 73-85. [CrossRef]

35. Matthes, L.; Ehn, J.; Girard, S.; Pogorzelec, N.; Babin, N.; Mundy, C.J. Average cosine coefficient and spectral distribution of the light field under sea ice: Implications for primary production. Elementa 2019, 7, 25. [CrossRef]

36. Light, B. Theoretical and observational techniques for estimating light scattering in first-year Arctic sea ice. In Light Scattering Reviews 5; Springer Praxis Books; Kokhanovsky, A., Ed.; Springer: Berlin/Heidelberg, Germany, 2010. [CrossRef]

37. Jassby, I.A.; Platt, T. Mathematical formulation of the relationship between photosynthesis and light for phytoplankton. Limnol. Oceanogr. 1976, 21, 540-547. [CrossRef]

38. Lund-Hansen, L.C.; Hawes, I.; Hancke, K.; Salmansen, N.; Nielsen, J.R.; Balslev, L.; Sorrell, B.K. Effects of increased irradiance and biomass, photobiology, nutritional quality, and pigment composition of Arctic sea ice algae. Mar. Ecol. Prog. Ser. 2020, 648, 95-110. [CrossRef]

39. Mundy, C.J.; Barber, D.; Michel, C. Variability of snow and ice thermal, physical and optical properties pertinent to sea ice algae biomass during spring. J. Mar. Sys. 2005, 58, 107-120. [CrossRef]

40. Matthew, S.; Massom, R.A. Snow in the sea ice system: Friend or foe? In Sea Ice, 3rd ed.; Thomas, D.N., Ed.; Wiley Blackwell: Oxford, UK, 2017; 652p. 